\title{
Laudatio na Petra Pakostu k udělení Ceny Josefa Vavrouška
}

\section{za rok 2013}

Martin Ríha

Envigogika 9 (2) - Inspirace/ Inspiration

Publikováno/Published 31. 10. 2014

DOI: $\underline{10.14712 / 18023061.456}$

\section{Abstrakt:}

Laudatio na Petra Pakostu při př́ležitosti udělení Ceny Josefa Vavrouška za rok 2013 Nadací Partnerství.

\section{Klíčová slova:}

Petr Pakosta; těžba uhlí; limity těžby

\section{Abstract:}

A speech delivered in praise of Petr Pakosta on the occasion of his receipt of the 2013 Josef Vavroušek prize by the Partnership Foundation.

\section{Keywords:}

Petr Pakosta; coal mining; mining limits 
Vážené dámy, vážení pánové, přátelé,

je mi ctí, že tu dnes mohu pronést laudatio na Petra Pakostu při přiležitosti udělení Ceny Josefa Vavrouška za rok 2013 Nadací Partnerství. Vnímám to však jako ocenění za celoživotní angažovanost ve prospěch životního prostředí, nikoliv jen za jeden rok. Petr Pakosta se za 76 let svého života stal osobností tak bohatou na zážitky, životní zkušenosti a občanskou angažovanost, že by to stačilo na několik životů. Petr se narodil v roce 1938 v Brandýse $\mathrm{n}$. Orlicí ve Východních Čechách. Jako dítě tam zažil 2. světovou válku a první léta po ní.

V roce 1953 šel po základní škole do učení. Vyučil se horníkem. Na Mostecko se dostal, jak tehdy bylo zvykem, na umístěnku. Po několika měsících na svobodárně zjistil, že pro něj město Most, měnící se z královského města s 650letou historií v Panelákov, není tím pravým. Našel si domek s demoličním výměrem v Hoře Sv. Kateřiny u potoka, jako byl zvyklý z dětství u Tiché Orlice. Domek začal kř́sit k novému životu. Dostal se na hlubinný důl Centrum, kde pracoval až do pracovního úrazu, který mu další fárání znemožnil. Doplnil si vzdělání o pedagogiku a učil 15 let na stavebním učilišti v Meziboří u Litvínova. Petr má dodnes dar pozorovacího talentu a schopnost vidět věci v souvislostech. Umí spojovat obecné s konkrétním a naopak, nepodléhá módě a názorovému mainstreamu, myslí originálně. Umí to i prodat, někdy s provokativní nadsázkou, nepostrádající racionální jádro ani humor. Brzy se proto začal kromě povolání zajímat i o věci veřejné jako občan, který není lhostejný k negativním jevům kolem. Tento jeho zájem nemohl přehlédnout devastaci krajiny $\vee$ SHP, rozvíjející se od 60. let a způsobovanou útlumem hlubinné těžby a obrovským rozvojem těžby povrchové. Sledoval odumírání lesů na Krušných horách působením emisí škodlivin do ovzduší z četných elektráren, chemiček a dalších průmyslových provozů v Podkrušnohoří. Viděl ničení sídel i památek, celého kulturního dědictví po původním obyvatelstvu v pohraničí i podhưř́ Krušných hor.

Za svého působení úředníka ONV Most pochopil, jak neúčinná je snaha (byt́ čestných) úředníků veřejné správy za socialismu čelit negativním tendencím v území. Od 70 . let minulého století proto vstupoval do ekologických hnutí a aktivit. Nejdříve Brontosaurus, ČsoP, spoluzakládal Spolek pro záchranu (a později obnovu) zámku Jezeř́. Pracoval v terénu i v osvětě, hledal a nacházel kontakty mezi vědci, odborníky, umělci, spolupořádal se spřizněnými dušemi, jako byl Milan Štovíček, akce $k$ probuzení občanské společnosti, např. besedy $v$ Docela malém divadle $v$ Litvínově. Jako člověk průbojný a asertivní se nebál oslovit místní, regionální ani ústřední politiky a klást jim nepř́ijemné otázky. Tak se mu brzy dostalo pozornosti nejen od duší spř́zněných, ale i od StB. Ve druhé polovině 80. let, když pod tlakem "perestrojky" v SSSR začala "normalizace" slábnout i u nás, využili environmentální aktivisté kontaktů a informací odborníků, jakými byli RNDr. Jan Marek ze Stavební geologie Praha, Ing. arch. Zdeněk Stáhlík a Ing. Igor Míchal, CSc. z Terplanu Praha, Ing. Marie Lafarová z VúvA Praha a další, $\mathrm{k}$ přímému oslovení představitelů státní moci a správy. Požadovali, aby namísto „šidítek", jakými byly kompenzační a stabilizační příspěvky na lepší životosprávu a kvalitnější dovolenou pracovníkům, kteří v postižené oblasti SHP žili a pracovali alespoň 10 let, začali konečně řešit příčiny zhoršujícího se stavu sídel, přírody, krajiny, zdravotního stavu i sociální struktury. Oslovili předsedu Severočeského KNV, místopředsedu KNV, zodpovědného za oblastní plán a životní prostředí, tajemníka KV KSČ a nakonec i tajemníka ÚV KSČ Rudolfa Hegenbarta. Dokázali přenést problémy těžby, energetiky, ochrany sídel, krajiny, památek i lidského zdraví v kraji až na jednání ústředních orgánů země a federace. 
Založili Ekofórum pánevní oblasti Severočeského kraje s právníkem Ing. Luborem Voleníkem. Už nikoliv jen intuitivně, ale s dobrými věcnými podklady, se začali dožadovat nápravných opatření v životním prostředí i v sociálních podmínkách obyvatel. Ještě před Listopadem 1989 tak docílili mimo jiné obnovení památkové ochrany zámku Jezeří, který už byl vyškrtnut ze seznamu památek a odsouzen k demolici ve prospěch těžby Velkolomu ČSA. Prosadili vymezení jeho ochranného pilíre, zahrnujícího i torzo zámeckého arboreta. To už se ale pod vlivem několikatýdenních inverzí s vysokými koncentracemi škodlivin v ovzduší začaly v ř́jnu 1989 plnit nejdříve čekárny lékařských ordinací, pak i ulice a náměstí lidmi, protestujícími proti způsobu hospodaření a vládnutí v kraji. Protesty začaly $v$ Teplicích a vše vyvrcholilo 17. listopadu 1989 v Praze a postupně v celé zemi.

Petr Pakosta se jako člen Ekofóra aktivně zúčastnil budování nových orgánů ochrany životního prostředí, podílel se na př́pravě prvních celostátních dokumentech MŽP a vlády k ozdravení životního prostředí v Severočeském kraji, a přitom pokračoval i v práci doma, na zámku Jezeří, v Litvínově, v Hoře Sv. Kateřiny. Stal se zastupitelem a místostarostou, využil svou hornickou erudici v obnově a zpřístupnění starých důlních děl na Hoře Sv. Kateřiny. Využívá navázaných kontaktů v dalším boji s těžařskou lobby dnešních (mezitím zpri-

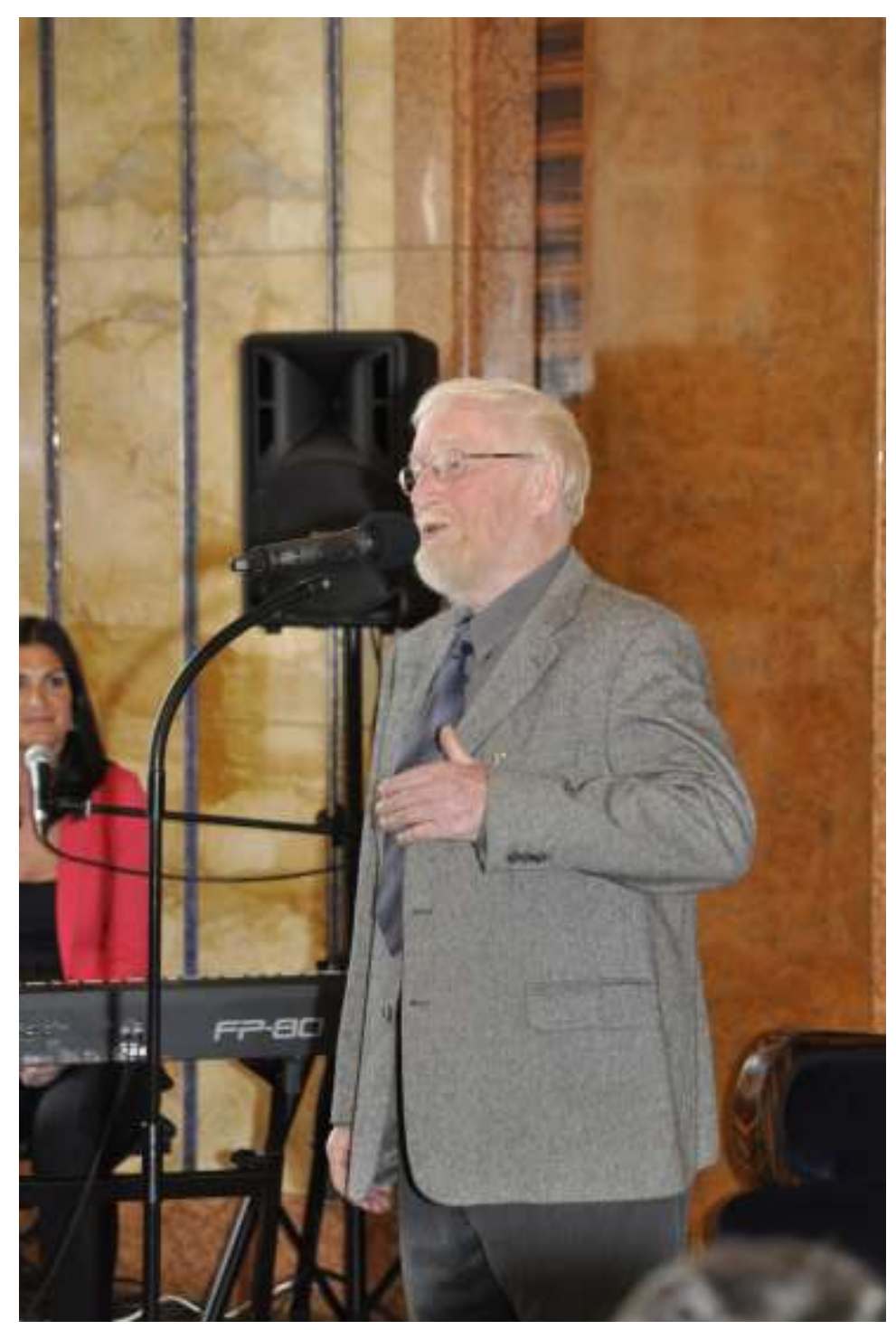
vatizovaných) dolů, při obnově staveb, znovunavázání přeshraničních styků se SRN po odstranění drátů, pomáhá $v$ ochraně prírody $a$ krajiny Krušných hor. Publikuje zajímavé texty, shromáždil a dovede zprostředkovat spoustu informací o historii kraje, těžby, o proměnách krajiny, osídlení i obyvatel. Na Hoře Sv. Kateřiny vybudoval ekologickou farmu, stal se členem Okresní agrární komory a hnutí Pro bio, než musel $\mathrm{s}$ věkem tuto farmářskou aktivitu předat následníkům.

Nepodlehl módním
kampaním a prosazuje zdravý selský rozum. Například jen přiměřený rozvoj turistiky, ale také třeba obnovitelných zdrojů, jako jsou větrné a solární elektrárny na Krušných horách. Je si vědom i jejich nevýhod a negativních vlivů. Nabádá k opatrnosti, k důkladnému hodnocení správnosti počtů i lokalizace, vlivů na okolí. Za své město a venkov bojuje ve Svazu měst a obcí při 
jednání o rozpočtovém určení daní. V roce 2008 šokoval iniciativou, kterou se zastupitelstvo města Hora Sv. Kateřina usneslo připojit se jako nová městská část k hlavnímu městu Praha s odůvodněním, že zatímco př́spěvek ze státního rozpočtu je $v$ Praze 38 tis. korun na trvale bydlícího obyvatele, na Hoře Sv. Kateřiny je to jen 8,6 tis. korun. Tato recese samozřejmě "neprošla", ale upozornilo to na závažný problém a dosáhli tak spolu s kolegy ze Svazu měst a obcí (SMO), že se za ministra Kalouska rozpočtové určení daní přeci jen poněkud upravilo ve prospěch malých obcí s obrovskými katastry, délkami komunikací, navíc v horských podmínkách s delší a tvrdší zimou.

Dodnes aktivně bojuje za zachování územních ekologických limitů těžby v SHP, za šetrnější energetickou i surovinovou politiku, za ochranu prírody, krajiny, sídel a památek kraje, za zdraví lidské populace. Přes svůj věk 76 let a zdravotní problémy je nadále aktivní. Je vzorem pro mnohem mladší $v$ občanské angažovanosti. Jsem rád, že toto ocenění Petr Pakosta dostává i za všechny své kolegy z Ekofóra i ze Spolku pro obnovu Jezeří, kteří se v roce 1988 u mne jako úředníka Severočeského KNV objevili spolu s RNDr. Janem Markem a Ing. arch. Zdeňkem Stáhlíkem s (tehdy tajnými) doklady o nestabilitě sutí i vnějších ker krystalinika Krušných hor, a tím začala naše společná cesta za záchranu jejich jižních svahů a bučin, zámku Jezeří, osady Černice a města Horního Jiřetína, za životní podmínky v Ústeckém kraji, která trvá dodnes. Blahopřeji čerstvému laureátovi Ceny Josefa Vavrouška a Vám děkuji za trpělivost a pozornost, s jakými jste mne vyslechli.

V Hradci Králové 14. května 2014 